\title{
Stages of Monitoring the Process of Managing the Creation of An Online Course
}

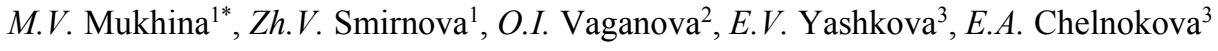 \\ ${ }^{1}$ Minin Nizhny Novgorod State Pedagogical University, Department of Technology of Service and \\ Technological Education, 603002, Nizhny Novgorod, Russia \\ ${ }^{2}$ Minin Nizhny Novgorod State Pedagogical University, Department of Professional Education and \\ Management of Educational Systems, 603002, Nizhny Novgorod, Russia \\ ${ }^{3}$ Minin Nizhny Novgorod State Pedagogical University, Department of Innovative Technologies of \\ Management, 603002, Nizhny Novgorod, Russia
}

\begin{abstract}
Management in education is one of the main tools that allow the rational use of various resources in order to achieve the objectives and improve work efficiency. The article shows the opportunities provided by management for the implementation of educational processes. The purpose of the work is to identify the need of using a checklist for placing an open online course on electronic educational platforms. Research methods: analysis of scientific literature, periodicals, publications on the topic of research, analysis of developed online courses and requirements for them. It has been revealed that the current level of development of information technology opens up opportunities for training for absolutely every person, regardless of age and health. The article discloses in detail one of the ways to realize this possibility - training using open online courses, analyzes the features of various educational platforms designed to host online courses. To place an open online course on any platform, it requires careful development. The need for using a checklist in the development and creation of an online course as a mandatory tool for monitoring by the developer has been identified, since a checklist is a predefined list of tasks or actions that are used as instructions. The article describes the need and advantages of using a checklist and presents one of the options for the checklist of the course "Concepts of modern science." An approximate algorithm for launching an online course by means of a developed checklist is presented. The necessary components of the document are determined, and the example of filling each component of the course "Concepts of modern science" is given in the paper. The checklist can be changed in accordance with the requirements for the development of a particular course, the features of the placement platform and the learning audience. The paper shows what opportunities are open for the course developer using a checklist.
\end{abstract}

\footnotetext{
* Corresponding author: mariyamuhina@yandex.ru
} 


\section{Introduction}

Management in education plays an important role in the development of the existing system, obtaining new ways and methods of work, as well as in the effective application and improvement of work results [1]. The combination and use of principles and methods of management with the specifics of the educational system allows more efficiently fulfill the basic tasks of the educational process, which in turn has a beneficial effect on the level of development of each individual and modern society as a whole $[2,3]$. One of the main trends in the development of modern education is its openness, accessibility of the educational environment for all citizens, regardless of their age, physical capabilities, remoteness from cultural and educational centers [4-7]. Therefore, the use of management tools contributes to the effective implementation of modern information technologies in the educational process and ensures a steady adherence to this trend $[8,9]$.

Today, everyone has the opportunity to study, to receive education at any level. One of the ways to realize this possibility is the development of massive open online courses. The development of such courses and their placement in an open educational environment is one of the tasks of modern universities [10-12].

The development of any online course requires careful preparation, this is a serious and lengthy process in which all the elements of the course should be integrated into the system, taking into account the target audience [13]. But creating a course and preparing it for placement, taking into account all the requirements of an open educational platform, requires control by the author-developer of the course. One of the tools for such control can be a checklist of the course.

Purpose of work: to identify the need and benefits of using a checklist for posting an open online course on electronic educational platforms.

Research Objectives:

1. To identify opportunities that open up for the course developer using a checklist;

2. Develop a checklist of the online course;

\section{Materials and Research Methods}

When writing an article, methods of analysis of scientific literature, periodic articles, and publications on the topic were used. The study was conducted in the form of an analysis of the developed online courses and the requirements for them from various open educational platforms.

\section{The Results of The Study}

During the study, we studied the courses of the most popular open educational platforms, such as edX, Coursera, Arzamas, Lektorium, Universarium, Stepik and others [14-16].

To place an open online course on any platform, it requires careful development. To do this, the developer must choose a platform for posting his online course, familiarize himself with the requirements for the development and placement of the course, develop the course in all its elements and configure all elements of the course. It is important not to lose sight of all the details and details. The development of the course checklist, that is, the list of necessary steps and the criteria for their development, will help to achieve this quality and control.

Translated from English, check means "check", and list means "list". Therefore, checklists are sometimes called "checklists." A checklist is a predefined list of tasks or actions that are used as instructions. Thus, a checklist is a list of step-by-step actions that must be 
performed in order to get a certain result in any work. It is simple to implement it, it is convenient to use it, and, as international experience shows, it can significantly reduce the number of errors in various fields of life. Checklists have been introduced in various professional fields where decisions are required.

Advantages of using check sheets:

1. Structuring information. When recording the necessary actions, the necessary sequence of tasks clearly emerges.

2. Improving the speed of learning. No need to repeat the sequence of operations. It is enough to conduct a short briefing and give a checklist for independent work.

3. High results, fewer errors. Check sheets help to avoid punctures and inattentive errors.

4. Interchangeability. Save time - significantly less time is spent on redoing tasks.

In this paper, we will present one of the options for the checklist of the course "Concepts of Modern Natural Science", prepared for placement on an electronic platform. A checklist is a non-standard document. It can be changed in accordance with the features of your course, the requirements of the platform, the characteristics of the target audience.

A sample checklist for launching an online course "Concepts of modern science" can look like this:

1. Believe the structure and composition of the course: the "Concepts of Modern Natural Science" course consists of sections and subsections that reveal its content. The main sections of the course: 1) Science as part of the culture. 2) Basic physical concepts. 3) Structural organization of inanimate nature. 4) The world as a whole. Man and the biosphere. Each section of the course includes subsections. Subsections are divided into blocks.

Table 1. The structure and composition of the course "Concepts of modern science"

\begin{tabular}{|c|c|c|}
\hline Sections & Subsections & Blocks \\
\hline \multirow[t]{3}{*}{$\begin{array}{l}\text { 1. Science as part of } \\
\text { culture }\end{array}$} & 11. Science and humanities & $\begin{array}{l}\text { - Video (Lecture) } \\
\text { - Text material (Workshop outline) } \\
\text { - Discussions (Seminar Discussion) } \\
\text { - Task (Test) } \\
\text { - Additional material (References) }\end{array}$ \\
\hline & $\begin{array}{l}\text { 1.2. Science as a way of knowing } \\
\text { the world }\end{array}$ & $\begin{array}{l}\text { - Video (Lecture) } \\
\text { - Text material (Workshop outline) } \\
\text { - Discussions (Seminar Discussion) } \\
\text { - Task (Test) } \\
\text { - Additional material (References) }\end{array}$ \\
\hline & $\begin{array}{l}\text { 1.3. Panorama and trends in the } \\
\text { development of natural sciences }\end{array}$ & $\begin{array}{l}\text { - Video (Lecture) } \\
\text { - Text material (Workshop outline) } \\
\text { - Discussions (Seminar Discussion) } \\
\text { - Task (Test) } \\
\text { - Additional material (References) } \\
\end{array}$ \\
\hline \multirow[t]{3}{*}{$\begin{array}{l}\text { 2. Basic physical } \\
\text { concepts }\end{array}$} & $\begin{array}{l}\text { 2.1. Corpuscular and continual } \\
\text { description of nature }\end{array}$ & $\begin{array}{l}\text { - Video (Lecture) } \\
\text { - Text material (Workshop outline) } \\
\text { - Discussions (Seminar Discussion) } \\
\text { - Task (Test) } \\
\text { - Additional material (References) }\end{array}$ \\
\hline & $\begin{array}{l}\text { 2.2. Fundamental theories and } \\
\text { principles of modern physics }\end{array}$ & $\begin{array}{l}\text { - Video (Lecture) } \\
\text { - Text material (Workshop outline) } \\
\text { - Discussions (Seminar Discussion) } \\
\text { - Task (Test) } \\
\text { - Additional material (References) }\end{array}$ \\
\hline & 2.3. Space and time & $\begin{array}{l}\text { - Video (Lecture) } \\
\text { - Text material (Workshop outline) } \\
\text { - Discussions (Seminar Discussion) } \\
\text { - Task (Test) }\end{array}$ \\
\hline
\end{tabular}




\begin{tabular}{|c|c|c|}
\hline & & - Additional material (References) \\
\hline & $\begin{array}{l}\text { 2.4. Fundamental theories and } \\
\text { principles of modern physics }\end{array}$ & $\begin{array}{l}\text { - Video (Lecture) } \\
\text { - Text material (Workshop outline) } \\
\text { - Discussions (Seminar Discussion) } \\
\text { - Task (Test) } \\
\text { - Additional material (References) }\end{array}$ \\
\hline $\begin{array}{l}3 . \quad \text { Structural } \\
\text { organization of } \\
\text { inanimate nature }\end{array}$ & $\begin{array}{l}\text { 3.1. Quantum-mechanical concept } \\
\text { of matter }\end{array}$ & $\begin{array}{l}\text { - Video (Lecture) } \\
\text { - Text material (Workshop outline) } \\
\text { - Discussions (Seminar Discussion) } \\
\text { - Task (Test) } \\
\text { - Additional material (References) }\end{array}$ \\
\hline & $\begin{array}{l}\text { 3.2. Chemical and physico- } \\
\text { chemical systems }\end{array}$ & $\begin{array}{l}\text { - Video (Lecture) } \\
\text { - Text material (Workshop outline) } \\
\text { - Discussions (Seminar Discussion) } \\
\text { - Task (Test) } \\
\text { - Additional material (References) }\end{array}$ \\
\hline & $\begin{array}{l}\text { 3.3. Systemic organization and } \\
\text { evolution of the universe }\end{array}$ & $\begin{array}{l}\text { - Video (Lecture) } \\
\text { - Text material (Workshop outline) } \\
\text { - Discussions (Seminar Discussion) } \\
\text { - Task (Test) } \\
\text { - Additional material (References) }\end{array}$ \\
\hline $\begin{array}{l}\text { 4. The world as a } \\
\text { whole. Man and the } \\
\text { biosphere }\end{array}$ & 4.1. Origin and essence of life & $\begin{array}{l}\text { - Video (Lecture) } \\
\text { - Text material (Workshop outline) } \\
\text { - Discussions (Seminar Discussion) } \\
\text { - Task (Test) } \\
\text { - Additional material (References) }\end{array}$ \\
\hline & $\begin{array}{l}\text { 4.2. Principles of evolution, } \\
\text { reproduction and development of } \\
\text { living systems }\end{array}$ & $\begin{array}{l}\text { - Video (Lecture) } \\
\text { - Text material (Workshop outline) } \\
\text { - Discussions (Seminar Discussion) } \\
\text { - Task (Test) } \\
\text { - Additional material (References) }\end{array}$ \\
\hline & 4.3. Man and the biosphere & $\begin{array}{l}\text { - Video (Lecture) } \\
\text { - Text material (Workshop outline) } \\
\text { - Discussions (Seminar Discussion) } \\
\text { - Task (Test) } \\
\text { - Additional material (References) }\end{array}$ \\
\hline & $\begin{array}{l}\text { 4.4. A single picture of the world - } \\
\text { the path to a single culture }\end{array}$ & $\begin{array}{l}\text { - Video (Lecture) } \\
\text { - Text material (Workshop outline) } \\
\text { - Discussions (Seminar Discussion) } \\
\text { - Task (Test) } \\
\text { - Additional material (References) }\end{array}$ \\
\hline Finaltesting & Final test at the course of the KSE & - Task (Test) \\
\hline
\end{tabular}

2. Check course settings:

- Course pages: Course home page. Course. Discussions Progress. Grading system. Teachers of the course.

- Course homepage: Course news. Additional materials. Control questions on the course.

- Course settings:

- Settings for the video: (Name (Display name of the component); Video is available only for online viewing - No; Link (Video ID (from the downloaded course materials in EVMS), Allow downloading)

- Settings for testing: (Questions with one answer or with multiple choice (Flags); Determine the weight of the task - 1 point; The number of tasks in all tests - 10; The maximum number of attempts - 3; The time between attempts - 15 minutes ( 900 seconds) ; The name 
of the test - by the name of the subsection; Set the "Reset" button; Show the correct answer When the attempt is used.

Final testing contains 30 questions. The weight of each task is 1 point. The number of attempts is 1 . Time limit is 30 minutes (1800 seconds). Show correct answers allow - When attempt is used.

- Deadlines: Set deadlines 1 week after the opening of each subsection.

- Timing of the course materials: Each subsection is the beginning of a new week (A total of 14 weeks in the course).

- Grading system: Each week - max 5\%. All material passed - max 70\%. Final testing $\max 30 \%$. Total - $100 \%$.

The rating is satisfactory - 55-70\% per course; the grade is "good" - 71-85\% per course; excellent rating - 86-100\% per course.

\section{Discussion}

The problem of developing, controlling an online course is significant, since the modern educational online environment makes high demands on educational resources. Each authordeveloper is responsible for the content of his course and its content. We gave an example of the checklist of the course "Concepts of Modern Natural Science". Note that some positions of the course checklist can be changed in accordance with the requirements for the development of the course. The research of this issue showed that the checklist is a nonstandard document. It should be developed in accordance with the features of the created course, platform requirements, and features of the target audience. Active development of this issue contributes to the filling of the open educational space with high-quality information materials.

\section{Conclusion}

Developing a course checklist is an important step in creating an algorithm for controlling the course's fullness and its compliance with modern requirements. In modern conditions of an abrupt transition of the educational system to distance learning, the developed algorithm will allow teachers quickly, efficiently create a product in demand. At the same time, this algorithm will provide a qualitative diagnosis of the developed course, since if it meets the sections highlighted in the checklist, it meets the standards and requirements for open online courses on electronic educational platforms. Thus, the successful development of modern online courses is ensured and the tendency for the implementation of information technologies in the educational space through the implementation of management tools in education is realized.

\section{References}

1. S. G. Mkrtchyan, Young sci. 45(283), 338-340 (2019)

2. H. Aldowah, H. Al-Samarraie, W. M. Fauzy, Telemat. Informat. 37, 13-49 (2019)

3. V. Kovanović, S. Joksimović, O. Poquet, Th. Hennis, D. Gašević, Internet Higher Educ. 40, 20-43 (2019)

4. N. C. Burbules, G. Fan, Ph. Repp, Geog. Sustain. (2020) (In press)

5. B. Toven-Lindsey, R. A. Rhoads, J. B. Lozano, Internet Higher Educ. 24, 1-12 (2015)

6. C. Paterson, N. Paterson, W. Jackson, F. Work, Nurse Educ. Today 85, (2020) 
7. E. Gryaznova, Azimuth Sci. Res. Pedagog. Psy. 8 4(29), 63-65 (2019)

8. M. V. Mukhina, A. S. Pletneva, Informatization of the education process, In Proceedings of the II All-Russian Scientific and Practical Conference «Social and technical services: problems and ways of development», Nizhny Novgorod, Russia (2015)

9. I. Srba, M. Savic, M. Bielikova, M. Ivanovic, C. Pautasso, Comp. Educ. 135 75-90 (2019)

10. M.V. Mukhina, Distance learning as a modern trend in the development of society $6(40)$, 57-64 (2019)

11. A. J. Scheerder, A. J. A. M. van Deursen, J. A. G. M van Dijk, Poetics 80, (2020)

12. G. Elia, G. Solazzo, G. Lorenzo, G. Passiante, Comp. Human Behav. 92, 589-599 (2019)

13. O. I. Vaganova, E. A. Aleshugina, K. A. Maksimova, Azimuth Sci. Res. Pedagog. Psy. 8 3(28), 57-59 (2019)

14. B. Kiselev, V. Yakutenko, Proc. Comp. Sci. 169 373-379 (2020)

15. J. van Dijck, Comp. Law Security Rev. 36105377 (2020)

16. Ya. Kolodina, The five largest online learning platforms. The largest educational platforms are collected in the review of RIAMO Available at: https://riamo.ru/article/231962/5-krupnejshih-platform-onlajn-obucheniya 